\title{
PENENTUAN ISI AWAL MINYAK DITEMPAT DENGAN MENGGUNAKAN METODEMATERIAL BALANCE DAN VOLUMETRIK PADA RESERVOIR ADZ
}

\author{
Dikky fathurochman sidiq ${ }^{1, a}$, Lestari Said ${ }^{2, b}$ \\ 1Jurusan Teknik Perminyakan Fakultas Teknik Perminyakan ,Universitas Trisakti, Indonesia \\ ${ }^{2}$ Program Studi Teknik Perminyakan, Fakultas Teknik, Universitas Trisakti, Indonesia \\ adikkyfaturochmansidiq@gmail.com, 'Lestari.said@yahoo.com
}

\begin{abstract}
Abstrak.
Penentuan isi awal minyak suatu reservoir dimulai sejak kegiatan eksplorasi. Pada tahap awal itulah penentuan cadangan minyak awal ditentukan. Hal ini bertujuan untuk memastikan apakah proyek tersebut dapat menguntungkan untuk perusahaan atau tidak. Seiring berjalannya waktu penentuan isi awal minyak ditempat terus dilakukan untuk meningkatkan ketelitian perhitungan dengan menggunakan metode material balance.

Pada reservoir "ADZ” jenis reservoirnya adalah undersaturated reservoir. Hal ini disebabkan karena tekanan awal pada tahun 1980 sebesar 2762.74 psia, sedangkan tekanan bubble point sebesar 1625.8 psia. Hingga tahun 2015 reservoir ini masih berada diatas tekanan bubble point dengan tekanan 1783.55 psia, reservoir ini juga tidak memiliki gas cap pada kondisi awal. Drive mechanism yang bekerja pada lapangan ini adalah solution gas drive.
\end{abstract}

Perhitungan isi awal minyak pada tugas akhir ini menggunakan 4 metode yaitu metode volumetric, metode material balance, garis lurus, dan software Mbal. Dengan menggunakan metode volumetric didapatkan cadangan awal minyak ditempat sebesar 174063462 STB, sedangkan perhitungan cadangan awal minyak di tempat dengan menggunakan metode material balance mendapatkan sebesar 176497285 STB. Persentase perbedaan isi awal minyak ditempat antara metode sebesar $<5 \%$.

\begin{abstract}
.
Determination of the initial oil content of a reservoir starts from exploration activities. In the initial stage, the determination of the initial oil reserves is determined. This aims to determine whether the project can be profitable for the company or not. Over time the determination of the initial contents of the oil continues to be carried out to improve the accuracy of calculations using the material balance method.
\end{abstract}

In the reservoir "ADZ" the type of reservoir is an undersaturated reservoir. This is because the initial pressure in 1980 was 2762.74 psia, while the bubble point pressure was 1625.8 psia. Until 2015 this reservoir was still above the bubble point pressure with a pressure of 1783.55 psia, this reservoir also had no gas cap in the initial conditions. The drive mechanism that works on this field is the solution for the gas drive.

Calculation of the initial content of oil in this final project uses 4 methods, namely volumetric method, material balance method, straight line, and Mbal software. Using the volumetric method, the initial oil reserves obtained at the place amounted to 174063462 STB, while the calculation of the initial oil reserves in place using the material balance method was 176497285 STB. The percentage difference in the initial content of oil between the methods is $<5 \%$. 


\section{PENDAHULUAN}

Mengembangkan suatu lapangan memerlukan data isi awal minyak di tempat atau disebut original oil in place (OOIP). penghitungan isi awal minyak dilakukan secara berkala karena akan berubah dari waktu ke waktu, Bertambahnya waktu maka semakin banyak data yang dimiliki,seperti data tekanan, produksi minyak, produksi air, dan prduksi gas. Banyaknya data dari suatu lapangan membuat penentuan isi awal minyak semakin akurat.

Reservoir ADZ adalah reservoir minyak yang memiliki 9 sumur, dansudah di produksi dari tahun 1980 hingga 2015 maka sumur ini telah berproduksi selama 35 tahun. Akumulasi produksi minyak adalah 9,3426 MMSTB, sedangkan produksi kumulatif gas telah diproduksi sebesar 102,117MMSCF, dan produksi akumulasi air sebesar 0,1734 MMSTB.

Pada tugas akhir ini beberapa perhitungan dilakukan untuk menentukan drive mechanism,original oil in place, danrecovery factor dari reservoir ADZ. Menentukan isi awal minyak di tempat memerlukan beberapa tahapan. Mengetahui tenaga dorong yang bekerjapada reservoir tersebut merupakan hal utama untuk menentukan isi awal minyak ditempat, karena setelah mengetahui jenis tenaga dorongnya akan mempermudah menentukan rumus pada metode material balace dan persamaan garis lurus sehingga perhitungan akan lebih mudah dan tempat

\section{Studi pustaka}

Penentuan isi awal minyak ditempat dapat dicari dengan menggunakan metode volumetric, metode material balance, garis lurus, dan sotware Mbal. Sedangkan untuk menghitung isi awal minyak ditempat yang dapat diproduksikan serta lamanya waktu berproduksi suatu lapanga ndigunakan metodematerial balance, garis lurus, dan software Mbal.

Beberapa data yang diperlukan antara lain : data geologi, data sifat-sifat fisik fluida, data analisa PVT. Data-data tersebut juga dapat dipergunakan untuk menentukan jenis tenaga dorong pada reservoir tersebut. Data seperti tekanan dan produksi dari sumur tersebut yang diambil setiap tahun selama sumur tersebut berproduksi juga dibutuhkan untuk menghitung isi awal minyak di tempat. Berikut akan dijelaskan mengenai parameter-parameter yang digunakan untuk metode perhitungan isi awal minyak ditempat serta mengenai mekanisme tenaga dorong.

\section{METODOLOGI PENELITIAN}

Penentuan isi minyak awal di tempat atau disebut Original Oil In Place (OOIP) bertujuan untuk menentukan pengembangan suatu lapangan minyak dan gas. Setelah lapangan berproduksi penghitungan isi awal minyak perlu kembali dilakukankarena sudahmemiki data produksidan data penurunantekanan sehinnga perhitungan lebih akurat. Reservoir ADZ telah berproduksi selama 35 tahun (1980-2015).

Metodeyang di gunakan dalam tugas akir ini adalah metode volumetric, metode material balance, metode persamaan garis lurus, dan software Mbal. Penggunaan beberapa metode ini bertujuan untuk membandingkan hasil isi awal minyak di tempat sehingga bisa ditentukan yang paling akurat. Metode material balance dianggap lebih akurat karena metode material balance menggunakan data yang lebih lengkap, data-data selama sumur tersebut berproduksi seperti data tekanan dan produksi.

Data yang di perlukan untuk menghitung isi awal cadangan minyak di tempat pada reservoir ADZ dengan menggunakan material balace berbeda dengan menggunakan metode volumetric. Berikut data yang diperlukan yaitu: data produksi, data tekanan, dan data PVT 
selamasumurtersebutberproduksidaritahun 1980 hingga 2015, berbeda dengan menggunakan metode volumetric data yang diperlukannya adalah: data PVT dan petrofisik.

\section{HASIL, PEMBAHASAN DAN ANALISA}

Pada tugas akhir ini bertujuan untuk menghitung isi cadangan awal minyak di tempat, metode yang digunaan adalah metode voumetric, metode material balance, garis lurus, dan software Mbal.Untuk mempermudah perhitungan isi cadangan awal minyak di tempat maka terlebih dahulu menentukan jenis tenaga dorong, metode yang digunakan untuk menentuan jenis tenaga dorong adalah: metode Ganesh Thakur, metodekualitatif, dan metode drive index

Reservoir ADZ sudah berproduksi dari tahun 1980 dengan tekanan awal sebesar 2762.74 psia. Jenis reservoir ini merupakan reservoir undersaturated dimana tekanan pada tahun terakhir (2015) sebesar 1783.55 psia, sedangkan tekanan bubble points ebesar 1625.8 psia.

Tabel

Tenaga Dorong Reservoir ADZ

\begin{tabular}{|c|l|}
\hline Metode & Drive Mechanism \\
\hline Kualitatif & Solution gas drive \\
\hline Ganesh thakur & Solution gas drive \\
\hline Drive Index & Solution gas drive \\
\hline
\end{tabular}

Setelah tenaga dorong dari reservoir ini diketahui, maka selanjutnya menghitung isi awal cadangan minyak di tempat pada reservoir ADZ, terdapat 4 metode yang digunakan yaitu metode material balance, metode volumetric, garis lurus, dan dengan menggunakan software Mbal.

Tabel

Perbandingan OOIP Pada Reservoir ADZ

\begin{tabular}{|c|c|}
\hline Metode & Original Oil In Place (STB) \\
\hline Volumetric & 174063462 \\
\hline Material Balance & 176497285 \\
\hline GarisLurus & 177000000 \\
\hline Software Mbal & 178000000 \\
\hline
\end{tabular}




\section{KESIMPULAN}

1. Reservoir ADZ berproduksi dari tahun 1980-2015 (35tahun), namun tekanan reservoir pada tahun 2015 (1783.55 psia) belum mencapai tekanan bubblepoin-nya (1625.8psia), sehingga termasuk reservoir undersaturated.

2. Jenis tenaga dorong reservoir ADZ adalah solution gas drive, diperoleh menggunakan tiga metode yaitu: metode Ganesh Thakur, metodekualitatif, dan metode drive index.

3. Setelah mengetahui jenis drive mechanism maka dilakukan perhitungan cadangan isi awal minyakmenggunakan 4 metode yaitu: metode material balance, metode volumetric, metode garis lurus, dan metode software Mbal.

4. Berikut hasil dari perhitungan cadangan isi awal minyak yaitu dengan metode material balance sebesar 176497285 STB, metode volumetric sebesar 174063 462, metode persamaan garis lurus sebesar 177 MMSTB, dan menggunakan metode sotware Mbal 178 MMSTB.

5. Hasill perhitungan recovery factorpada reservoir ADZ adalah sebesar 5,37 \%.

\section{DAFTAR PUSTAKA}

Ahmed, Tarekh and McKiney., "Advance Reservoir Engineering", Gulf Profesional Publishing, Oxford, 2004.

Ahmed, Tarekh, "Reservoir Engineering Hand Book", 2ed, Gulf Profesional Publishing, Oxford, 2006.

Thakur, Ganesh "Integrated Petroleum Reservoir Management : a Team Approach", Pennwell Publishing Company, Oklahoma, 1994.

Sumantri, R., "Buku Pelajaran Teknik Reservoir I", Diktat, Universitas Trisakti, Jakarta, 1998.

Diktat Praktikum Analisa Batuan Reservoir, Universitas Trisakti, Jakarta. http://www.indoinc.com/pespecialists/HAVLENA.html.

Rukmana, Dadang., "Teknik Reservoir TeoridanAplikasi”, PohonCahaya, Yogyakarta. 2012.

Amyx, j et.al.,"Petroleum Reservoir Engineering Physical properties", McGraw Hill Inc, Texas, 1960.

Craft and Hawkins, "Apply Petroleum Reservoir”, 2ed, Prentice-Hall Inc, New Jersey, 1991.

http://fatmapetroleum.blogspot.com/2011/06/material-balance.htmlscience. 